\title{
Criminal Injury
}

National Cancer Institute

\section{Source}

National Cancer Institute. Criminal Injury. NCI Thesaurus. Code C35628.

Trauma resulting from illegal activity. 